\title{
CD133 and MYCN Amplification Induce Chemo-Resistance and Reduce Average Survival Time in Pediatric Neuroblastoma
}

\author{
Zhi-Yong Zhong*, Bao-Jun Shi, Hui Zhou and Wen-Bo Wang
}

Department of Pediatric Surgery, The Second of Hospital of Hebei Medical University, PRChina

\begin{abstract}
Objectives: Neuroblastoma (NB) is the most common pediatric solid tumor derived from the sympathetic nervous system. MYCN gene exists in nearly half of the NB patient and its association with rapid disease progression and poor outcome is controversial. Cancer Stem Cells (CSCs) characterization in NB has been rarely studied. This study is to figure out whether the MYCN gene and CSCs are associated with chemotherapy resistance and survival time in the NB patients.
\end{abstract}

Methods: Based on unequivocal pathological diagnosis, 50 NB patients are recruited. MYSN amplification is measured before any therapy. The CSCs are derived and their multi-potencies are tested by directed differentiation. Response to chemotherapy and average survival time of these patients are gathered and compared with following groups: CD133+, CD133-, MYCN $\geq 5, M Y C N<5, C D 133+$ plus $M Y C N \geq 5, C D 133$ - plus $M Y C N<5$.

Results: CD133+ CSCs differentiate into neuron like cells; CD133+ patients have significant poorer response to chemotherapy comparing with the CD133- patients $(P<0.01)$; CD133+ and MYCN $\geq 5$ patients have significantly shorter average survival time than the $C D 133-$ and $M Y C N<5$ patients $(P<0.01)$.

Conclusions: CD133+ CSCs produce chemo-resistance. CD133 and MYCN amplification can be used together as a prognostic value for predicting disease outcome.

Keywords: Cancer stem cells; CD133; Chemo-resistance; MYCN; Neuroblastoma

\section{Introduction}

Neuroblastoma (NB) is the most common extracranial pediatric solid tumor. NB tumor cells are embryonic neural crest-derived cells, which give rise to the nerve cells of the sympathetic nervous system in normal development $[1,2]$. It is widely assumed that NBs are embryonic tumors originating from a developmental defect that prevents normal cell differentiation and gets stuck in a continuous replication status $[3,4]$. It most frequently originates in the adrenal medulla and paraspinal or pariaortic regions where the sympathetic nerve tissues are present from neck to pelvis $[5,6]$

The prevalence of NBs is about one in 7000 live births; the incidence is about 10.54 cases per 1 million per year in the children younger than 15 years [7]. About $90 \%$ are younger than 5 years at diagnosis, $37 \%$ are infant, the median age of diagnosis is 19 months [8]. Most NB cases are sporadic, only $1 \%$ to $2 \%$ patients have family history of NB. The most common symptom of NB is an abdominal mass, and other signs include proptosis and periorbital ecchymosis, abdominal distention, bone pain, pancytopenia, fever, hypertension, anemia, paralysis and watery diarrhea etc $[9,10]$. The clinical course is heterogeneous ranging from spontaneous regression in neonates to life-threatening metastatic disease in older children [5]. The medical treatments include observation, chemotherapy, surgery, immunotherapy, autologous peripheral blood stem cell transplantation (APBSCT). Since the five-year survival rate was significantly improved in recent five years, high-risk NBs are still remain the most difficult tumor to cure, with only $40 \%$ of long-term survival despite intensive multi-modal therapy $[6,11,3]$.

In recent years, accumulating evidence demonstrates that tumor is a hierarchy organization regulated by a minority of cells, called Cancer Stem Cells (CSCs) [12-14]. CSCs constitute less than $1 \%$ of tumor cells and have exclusive ability to self-sustain and self-renew to generate heterogeneous lineages of cancer cells to comprise the tumor [15]. The existence of self-renewing and multi-potent CSCs in NBs was partially addressed by Ross's research team [16,17]. Kaplan's research demonstrated that dissociated cells from aggressive NB tumors grew like spheres, differentiated into neurons, and formed NB tumors when orthotopically injected into severe combined immunodeficient/ Beige mice [18]. CD133 is a cell-surface glycoprotein harboring five transmembrane domains [19]. Knocking down of the CD133 in NB cells effectively resulted in cell growth retardation [20]. Up-regulated CD133 decreased sensitivity to cytostatics in clinic [21]. Whether $\mathrm{CD} 133^{+}$cells have effects on responses towards chemotherapy and average survival time need to be demonstrated. At the best of our knowledge, there is no data has been published on this point.

MYCN amplification (defined as more than 10 copies per diploid genome) exists in $40 \%$ to $50 \%$ of high-risk NBs [22,23]. Most unfavorable clinical and pathobiological features are associated, to some degree, with MYCN. However, there is controversial study demonstrated MYCN is not related to the NB progression [24,25]. Whether MYCN amplification is associated with the NB progression needs to be further studied.

The purpose of this study is to demonstrate that whether the MYCN

${ }^{*}$ Corresponding author: Dr. Zhi-Yong Zhong, Pediatric Surgery Department, The Second Hospital of Hebei Medical University, 215 Heping West Road, Shijiazhuang PR China, Tel: +86 1324122 2181; E-mail: hbydmike99@163.com

Received July 28, 2017; Accepted July 29, 2017; Published July 31, 2017

Citation: Zhong ZY, Shi BJ, Zhou H, Wang WB (2017) CD133 and MYCN Amplification Induce Chemo-Resistance and Reduce Average Survival Time in Pediatric Neuroblastoma. J Stem Cell Res Ther 7: 394. doi: 10.4172/2157. 7633.1000394

Copyright: @ 2017 Zhong ZY, et al. This is an open-access article distributed under the terms of the Creative Commons Attribution License, which permits unrestricted use, distribution, and reproduction in any medium, provided the original author and source are credited. 
amplification and existance of the CD133 positive cells in the NBs are correlated with chemo-resistance and average survival time. We recruit NB patients, collect peripheral blood to measure MYSN amplification levels before any therapy. After surgery, CSCs are derived, and the CD133+ cells are calculated. The correlation of MYSN amplification and CD133+ CSCs with disease severity and overall survival rate is statistically calculated.

\section{Materials and Methods}

\section{Patient recruitment}

This study was reviewed and approved by The Second hospital of Hebei Medical University Ethics Committee before the study began. Written informed consent was provided to participates recruited into this study. The minimum criterion of a diagnosis of NB must be based on one of the following: an unequivocal pathological diagnosis from tumor tissue by light microscopy determined by the International Neuroblastoma Pathology Classification; the combination of bone marrow aspirate or trephine biopsy containing unequivocal tumor cells and increased levels of urinary catecholamine metabolites [26]. The recruitment started from Jan 2014 and finished in May 2016.

The International Neuroblastoma Staging System (INSS) stratifies neuroblastoma according to anatomical presence at diagnosis: stage I, IIa, IIb, III, IV, and IVS $[1,3,4]$. The International Neuroblastoma Risk Group Staging System (INRGSS) classifies NB into four pre-treatment groups: very low, low, intermediate and high risk [27]. In this study, we recruited 50 patients from 3 months to 8 years old, NB stages from IIa to IV. The INRGSS classification of these NB patients are from very low to high risk. The characteristics of patients recruited into this study are present in Table 1.

\section{Clinical treatments}

In this study, the MYCN amplification was calculated before any therapy. For very low risk NB patients, intensive observation every two months after surgery is carried on in clinic; for low risk, intermediate and high risk NB patients, surgery is performed before or during chemotherapy. For the patients over 18 months old, radiotherapy is used after chemotherapy; Criteria for chemotherapy must reach following clinical conditions before usage: no uncontrolled infection and organ dysfunctions, Alanine Transaminase (ALT) level is less than three-fold higher than the normal level, total bilirubin level is less than 1.5 fold higher than the normal level, Neutrophils Absolute Value (NAC) is over $1.0-1.2 \times 10^{9} / \mathrm{L}$ and platelets numbers is over $75 \times 10^{9} / \mathrm{L}$.

The chemical therapy protocol for low to intermediate risk NB

\begin{tabular}{|c|c|c|}
\hline Parameters & & Number of patients (\%) \\
\hline \multirow{2}{*}{ Sex } & Boys & $28(56)$ \\
& Girls & $22(44)$ \\
\hline \multirow{2}{*}{ Age (months) } & Range & $12-168$ \\
& Median & 24 \\
\hline \multirow{3}{*}{ INSS stages } & Ila & $8(16)$ \\
& Ilb & $16(32)$ \\
& III & $15(30)$ \\
\hline \multirow{2}{*}{ INRGSS stages } & IV & $11(22)$ \\
& Very low & $4(8)$ \\
& Low & $20(40)$ \\
\hline \multirow{3}{*}{ MYCN amplification } & Intermediate & $17(34)$ \\
& High & $9(18)$ \\
& $\geq 5$ times & $21(56)$ \\
& $<5$ times & $27(40)$ \\
\hline & No result & $2(4)$ \\
\hline
\end{tabular}

Table 1: Patients characteristics. patients is as following: $\left(1.5 \mathrm{mg} / \mathrm{m}^{2}\right)+\mathrm{CBP}\left(550 \mathrm{mg} / \mathrm{m}^{2}\right)+\mathrm{ADR}(30 \mathrm{mg} /$ $\left.\mathrm{m}^{2}\right)+\mathrm{CTX}\left(1.0 \mathrm{~g} / \mathrm{m}^{2}\right)$ for the first cycle, VCR $\left(1.5 \mathrm{mg} / \mathrm{m}^{2}\right)+\mathrm{CBP}(550 \mathrm{mg} /$ $\left.\mathrm{m}^{2}\right)+\mathrm{VP} 16\left(160 \mathrm{mg} / \mathrm{m}^{2}\right)+\mathrm{CTX}\left(1.0 \mathrm{~g} / \mathrm{m}^{2}\right)$ for the second cycle. These two cycles rotate to use. 9 -cis-RA is $150-160 \mathrm{mg} / \mathrm{m}^{2}$ for 6 months. For high risk NB patients, the chemical therapy protocol is as following: VCR (1.5 $\left.\mathrm{mg} / \mathrm{m}^{2}\right)+\operatorname{CDDP}\left(25 \mathrm{mg} / \mathrm{m}^{2}\right)+\mathrm{VP} 16\left(100 \mathrm{mg} / \mathrm{m}^{2}\right)+\mathrm{CTX}\left(1.0 \mathrm{~g} / \mathrm{m}^{2}\right)$, IFOS $\left(1.5 \mathrm{mg} / \mathrm{m}^{2}\right)+\mathrm{CBP}\left(550 \mathrm{mg} / \mathrm{m}^{2}\right) \mathrm{THP}\left(30 \mathrm{mg} / \mathrm{m}^{2}\right)$. These two cycles rotate to use. 9 -cis-RA is $150-160 \mathrm{mg} / \mathrm{m}^{2}$ for 6 months. For the patients whose body weights is less than $12 \mathrm{~kg}$, the concentrations of chemical drugs are as following: VCR $(0.05 \mathrm{mg} / \mathrm{kg}), \mathrm{CBP}(16 \mathrm{mg} / \mathrm{kg}), \mathrm{ADR}(1 \mathrm{mg} / \mathrm{kg})$, CTX (33 mg/kg), VP16 (5 mg/kg), 9-cis-RA (5.33 mg/kg/d), CDDP (0.85 mg/ $\mathrm{kg})$, IFOS (50 mg/kg), THP (1 mg/kg).

\section{MYCN amplification}

Total RNA is extracted from the NB patient and healthy volunteer peripheral blood. Total RNAs are extracted using RNeasy columns (Qiagen) according to the manufacture instructions. Total RNA (1 g) is reverse transcribed into cDNA (Clontech). SYBR green real-time PCR kit (Applied Biosystems) is used to quantify gene expression levels. Data is analyzed with SDS Relative Quantification Software version 2.2.2 (Applied Biosystems). Ct values were exported into Excel software for data analysis. The MYCN amplification levels are compared between the NB patients and healthy volunteers. MYCN forward primer is: TCTCTCCGAGCAGCGCA. MYCN reverse primer is: TGGCAGCAGGAGACCC.

\section{Tissue dissection and preparation of single cell suspension}

Tumor samples are collected and derived for the CSCs immediately. The tumor tissue is isolated and minced with a scissor, and rinsed with HBSS solution (without $\mathrm{Ca}^{2+}$ and $\mathrm{Mg}^{2+}$ ) (Life Technologies, 14170112) with $20 \%$ fetal bovine serum (FBS)

(Life Technologies, 10439001) at least three time to get rid of blood. Equal amount of the minced tissue is separated into three $15 \mathrm{ml}$ centrifuge tubes. The tissue pieces were incubated at $37^{\circ} \mathrm{C}$ for $15 \mathrm{~min}$ in $10 \mathrm{~mL}$ of dissociation solution: HBSS (without $\mathrm{Ca}^{2+}$ and $\mathrm{Mg}^{2+}$ ) supplemented with $0.015 \mathrm{M}$ HEPES (Life Technologies), $5.4 \mathrm{mg} / \mathrm{ml} \mathrm{D}$-glucose, $0.25 \%$ trypsin (Life Technologies, 15050057), $80 \mathrm{U} / \mathrm{ml}$ DNase (Sigma), 0.7 $\mathrm{mg} / \mathrm{ml}$ hyaluronidase (Sigma), and $2 \mathrm{mg} / \mathrm{ml}$ kynerenic acid (Sigma), followed by gentle trituration, and incubation in the same solution at $37^{\circ} \mathrm{C}$ for another $10 \mathrm{~min}$. Excess solution was removed and the tissue further mechanically dissociated to a single-cell suspension.

\section{Neurosphere cultures}

Single cells are plated at a density of 100 cells per well in 6-well ultralow attachment multiwall polystyrene plates (Falcon, Becton Dickinson, Franklin Lakes, NJ, USA) in a serum-free expansion medium composed of a 1:1 mixture of Dulbecco's Modified Eagle's Medium (DMEM) and Ham's F12 Nutrient Mixture (Life technologies), supplemented with $40 \mathrm{ng} / \mathrm{ml}$ epidermal growth factor (R\&D Systems), $20 \mathrm{ng} / \mathrm{ml}$ basic fibroblastic growth factor (R\&D Systems), 1\% B27 supplement (Life Technologies), $2 \mu \mathrm{g} / \mathrm{ml}$ heparin (Sigma Aldrich) and 100 units $/ \mathrm{ml}$ penicillin/streptomycin. Cultures are maintained at $37^{\circ} \mathrm{C}$ in a humid atmosphere with $95 \% \mathrm{O}_{2}$ and $5 \% \mathrm{CO}_{2} .50 \%$ of culture medium is changed with fresh medium with fresh growth factors every other day. After 7 days, neurospheres are either processed for FACS analysis or passaged by mechanical dissociation and re-suspended.

\section{CSCs differentiation into neurons}

The 6 well plates are coated with $20 \mathrm{mg} / \mathrm{ml}$ Poly-L-ornithine (Sigma, 
P4957) for at least two hours in the incubator. The Poly-L-ornithine solution is taken away, and the plate is rinsed once with water. $5 \mathrm{mg} /$ $\mathrm{ml}$ Laminine (Sigma, L2020) is added into the plate and stayed in the incubator for one hour. Use PBS water to rinse once just before use. Neurospheres are mechanically dissociated and digested with $0.25 \%$ Trypsin for 10 minutes. Then the isolated single cells are plated on coated 6-well plates. Mix glial cell culture medium (kindly provided by Dr. Zhi-Zhao Ma) with DMEM and L-Glutamine at the ratio of 1:1, plus 1\% FBS, $100 \mathrm{nM}$ all-trans-retinoic acid (Sigma, R2500), $20 \mathrm{ng} / \mathrm{ml}$ brain derived neurotrophic factor (BDNF, Millipore, 203702), $20 \mathrm{ng} / \mathrm{ml}$ neurotrophin 3 (NT-3, Millipore, GF308).

\section{Fluorescence activated cell sorting (FACS)}

Cells were mechanically dissociated to obtain a single-cell suspension in a solution containing $2 \mathrm{~mm}$ EDTA (Sigma) and 0.5\% FBS (Sigma) in PBS. Cells are harvested by centrifugation $\left(500 \mathrm{~g}, 5 \mathrm{~min}, 4^{\circ} \mathrm{C}\right)$, incubated with anti-mouse CD133 antibody (Chemicon), then incubated with secondary antibody conjugated with phycoerythrine (PE) for 2 hours on ice, washed with PBS twice then filtering through a 70- $\mu \mathrm{m}$ cup filter (Falcon) and kept on ice until FACS analysis. Cos7 cells are used as a negative control, liver tumor cells (known as high CD133 expression, kindly provided by $\mathrm{Dr}$. Jun Li) are used as a positive control. Cell sorting is performed on a FACS Vantage TS flow cytometer (Becton Dickinson, San Jose, CA, USA).

\section{Immunohistochemistry}

The cells are fxed with $4 \%$ paraformaldehyde for 10 minutes at room temperature. After being blocked with 5\% normal goat serum in PBS, are incubated with primary antibody neuronal class III b-tubulin antibody (Chemicon, MAB1637) overnight at $4^{\circ} \mathrm{C}$. After being washed for 3 times with PBS, the cells are incubated with secondary antibody Alexa Fluro ${ }^{\circ}$ 647-AffniPure Goat anti-Mouse IgG (Jackson ImmunoResearch, 115-605-205) for 2 hours at room temperature. The labeled slides are dehydrated in alcohol and xylene before being cover-slipped with mounting media.

\section{Statistical analysis}

Numerical data is expressed as mean \pm standard deviation (SD). Paired Student's t-test (two tailed) is used for statistical analysis using SPSS.v16.0 for windows (SPSS Inc., Chicago, IL, USA). P values less than 0.05 is considered statistically significant and indicated with ${ }^{*}$; $P$ values less than 0.01 were indicated with ${ }^{* *}$.

\section{Results}

\section{CT and pathological images of a particular NB patient}

The CT tumor images of a specific NB patient are shown in Figure $1 \mathrm{~A}$ and $1 \mathrm{~B}$. Figure $1 \mathrm{~A}$ is a CT image before routine chemotherapy; Figure $1 \mathrm{~B}$ is a CT image after chemotherapy of the same patient. The solid tumor almost disappears after chemotherapy. Most NB patients get partial response towards chemotherapy unfortunately. Figure $1 \mathrm{C}$ and $1 \mathrm{D}$ are pathological images of the NB tumor stained by $\mathrm{H} \& \mathrm{E}$ staining. On microscopy, the tumor cells are typically small, round and blue, and rosette patterns.

\section{CSCs derived from the NB can form neurosphere}

Once the tumor tissue is separated int single cells, these single cells are plated on low attachment plates and grow in serum free medium with growth factors. As shown in Figure 1E, it is the third day after plating. Figure $1 \mathrm{~F}$ shows the seventh day after plating. The neurospheres grows bigger. These phenomenon demonstrates that there are CSCs existing inside of the neurosphere.

\section{CSCs can differentiate into neuron like cells}

As multipotent stem cells, CSCs can differentiate into somatic cells. Whether the CSCs derived from the NB tissue can differentiate into neuron cells determines its identity. As shown in Figure 2A and 2B, once the neurospheres attaches to the bottom of plate, cells crawl out of the cell cluster. When the medium changes into neuron supporting medium for 2 weeks, the neuron like cells appear as shown in Figure 2C. These cells are b-tubulin positive as shown in Figure 2D, demonstrating that these cells are neurons.

\section{FACS results for separating $\mathrm{CD} 33^{+}$cells from the CSCs}

Cos7 cells are used as negative control as shown in Figure 3A, liver tumor cells known has high CD133 expression level are used as positive control as shown in Figure 3B. The neurospheres are harvested and stained with CD133 antibody. FACS shows that there are $0.1 \%$ CD133 positive cells in the CSCs derived from the NB tissue as shown in Figure 3C. These results demonstrates that there are cancer stem cells existing in the NB tissue. Whether and how these stem cells influence cancer pathophysiology and reaction towards to chemical therapy needs to be further studied (Table 2).

Correlation between CD133+ and MYCN amplification with chemotherapy response and average survival time Complete response, very good partial response and partial response are used to measure patient response towards chemotherapy in clinic. CD133+ NB patients have significant less chance to have complete response $(\mathrm{P}<0.01)$, very good partial response and partial response $(\mathrm{P}<0.05)$ than $\mathrm{CD} 133$ patients .However, CD133 expression has no significant influence on average survival time $(\mathrm{P}>0.05)$; MYCN amplification over 5 folds has similar effects on chemotherapy response with CD133 expression. However, MYCN amplification over 5 folds can significantly decrease average survival time comparing with MYCN amplification less than 5 folds $(\mathrm{P}<0.05)$; $\mathrm{CD} 133+\mathrm{NB}$ patients who have MYCN amplification over 5 folds has significant shorter average survival time comparing with CD133- and MYCN amplification less than 5 folds $(\mathrm{P}<0.01)$ (Table 3 and Figure 4).

\begin{tabular}{|c|c|c|c|}
\hline Samples & $\begin{array}{c}\text { Cos7 as the } \\
\text { negative control }\end{array}$ & $\begin{array}{c}\text { Liver tumor cells as } \\
\text { positive control }\end{array}$ & NB sample \\
\hline Percentage of CSCs & 0 & $15 \%$ & $0.1 \%$ \\
\hline
\end{tabular}

Table 2: CSCs percentages summary. There is $8.5 \%$ of CD133+ cells in liver tumor cells. There is only $0.1 \%$ of CD133+ cells in CSCs derived from neuroblastoma.

\begin{tabular}{|c|c|c|c|c|c|}
\hline Parameters & Patients & $\begin{array}{c}\text { Complete } \\
\text { response } \\
(\%)\end{array}$ & $\begin{array}{c}\text { Very good } \\
\text { partial } \\
\text { response } \\
(\%)\end{array}$ & $\begin{array}{c}\text { Partial } \\
\text { response } \\
(\%)\end{array}$ & $\begin{array}{c}\text { Average } \\
\text { survival } \\
\text { (months) } \\
\text { (Average } \pm \text { SD) }\end{array}$ \\
\hline CD133+ & 12 & $1(8)$ & $2(17)$ & $9(75)$ & $36.3 \pm 6.9$ \\
\hline CD133- & 38 & $8(21)^{\star *}$ & $19(50)^{\star}$ & $11(29)^{*}$ & $41.5 \pm 9.8$ \\
\hline MYCN $\geq 5$ & 21 & 0 & $7(33)$ & $14(67)$ & $24.6 \pm 4.7$ \\
\hline MYCN <5 & 27 & $9(33)^{\star *}$ & $12(45)$ & $6(22)^{*}$ & $40.2 \pm 6.9^{*}$ \\
\hline $\begin{array}{c}\text { CD133+ and } \\
\text { MYCN } \geq 5\end{array}$ & 10 & $1(10)$ & $2(20)$ & $7(70)$ & $12.4 \pm 2.8$ \\
\hline $\begin{array}{c}\text { CD133- and } \\
\text { MYCN<5 }\end{array}$ & 25 & $8(32)^{* *}$ & $12(48)^{*}$ & $5(20)^{\star *}$ & $42.7 \pm 8.3^{\star *}$ \\
\hline
\end{tabular}

Table 3: Correlation between CD133 and MYCN amplification, ${ }^{*} \mathrm{P}<0.05 ;{ }^{* *} \mathrm{P}<0.01$ $\mathrm{CD} 133+$ and/or $\mathrm{MYCN} \geq 5$ can significantly decrease response to chemical therapy comparing with $\mathrm{CD} 133-$ and/or $\mathrm{MYCN}<5(\mathrm{P}<0.05)$. 
Citation: Zhong ZY, Shi BJ, Zhou H, Wang WB (2017) CD133 and MYCN Amplification Induce Chemo-Resistance and Reduce Average Survival Time in Pediatric Neuroblastoma. J Stem Cell Res Ther 7: 394. doi: 10.4172/2157-7633.1000394

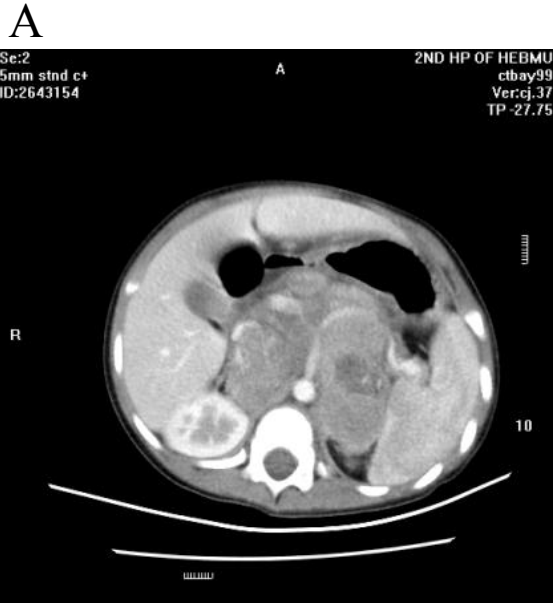

$\mathrm{C}$

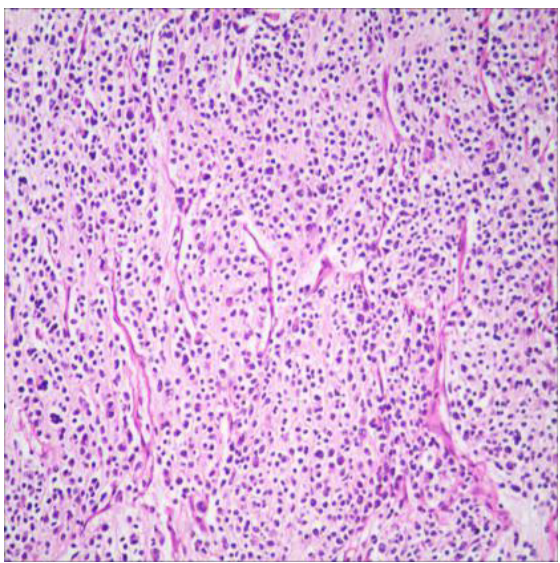

$\mathrm{E}$

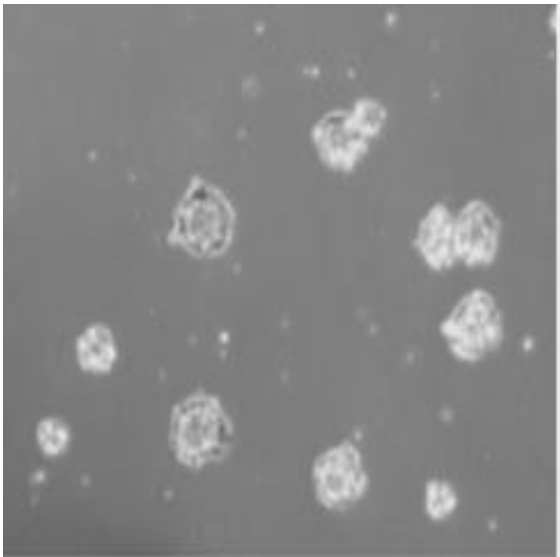

B

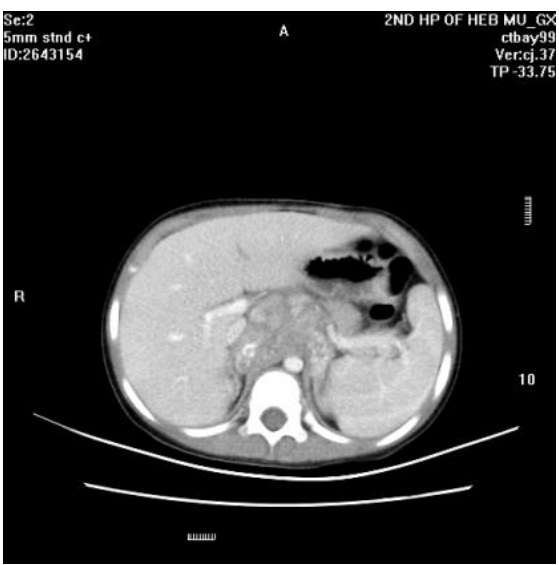

$\mathrm{D}$

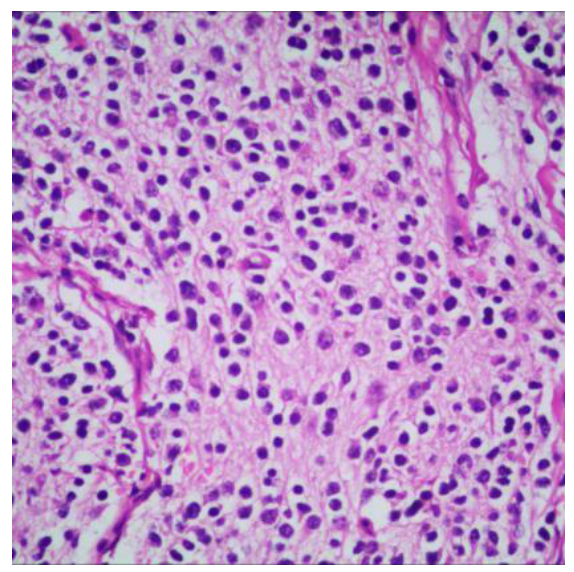

$\mathrm{F}$

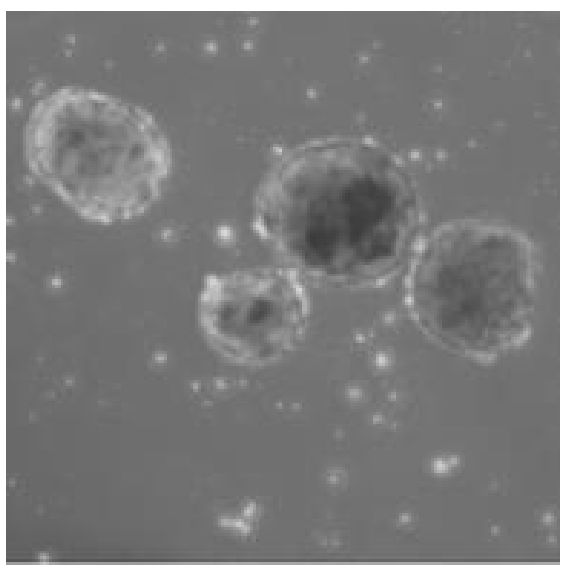

Figure 1: CT and pathological images of a particular NB patient. A is a CT image before routine chemotherapy; $\mathbf{B}$ is a CT image after chemotherapy of the same patient. The solid tumor almost disappears after chemotherapy. $\mathbf{C}$ and $\mathbf{D}$ are pathological images of the NB tumor stained by $H$ \& $E$ staining. On microscopy, the tumor cells are typically small, round and blue, and rosette patterns. $\mathbf{E}$ and $\mathbf{F}$ are images of neurospheres on day 3 and day 7 after tumor separated and grew as single cells.

\section{Discussion}

Neuroblastoma (NB) is the most common pediatric solid tumor derived from the sympathetic nervous system. The clinical course is heterogeneous ranging from spontaneous regression in neonates to lifethreatening metastatic disease in older children. MYCN amplification level is recruited into the INRGSS system, and it is used to predict patient survival time and direct clinical treatment protocol. However, it 
A

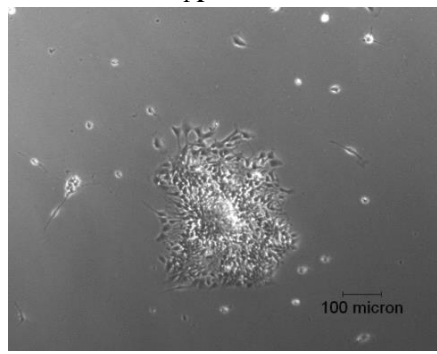

$\mathrm{C}$

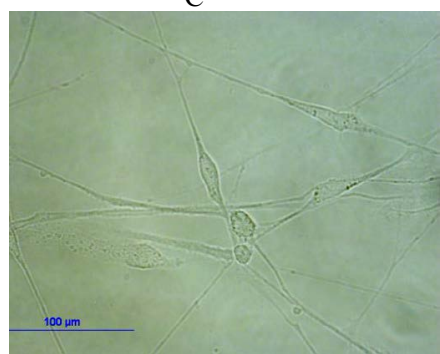

B

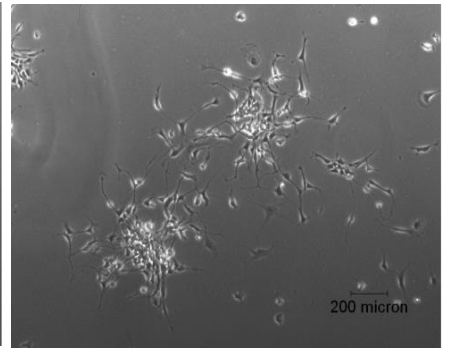

$\mathrm{D}$

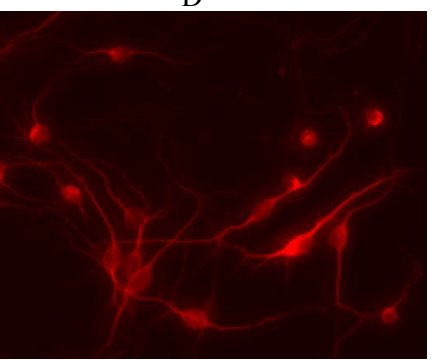

Figure 2: CSCs can differentiate into neuron like cells. Floating neurospheres can attach to the coated plate bottom and cells can crawl out of the cell cluster as shown in $\mathbf{A}$ and $\mathbf{B}$; Under the neuron growth medium, these CSCs can differentiate into neuron like cells as shown in figure $\mathbf{C}$, which can be stained positive by using b-tubulin antibody as shown in figure $\mathbf{D}$. This suggests that these cells are neurons.

A

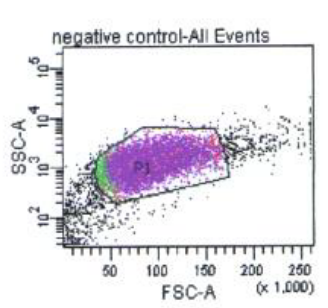

$\mathrm{B}$
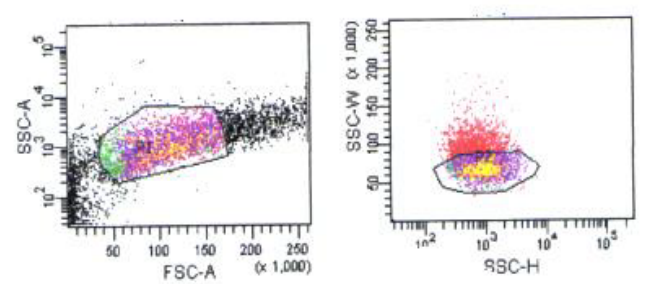

$\mathrm{C}$
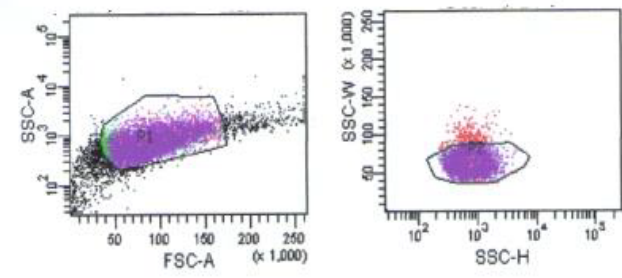
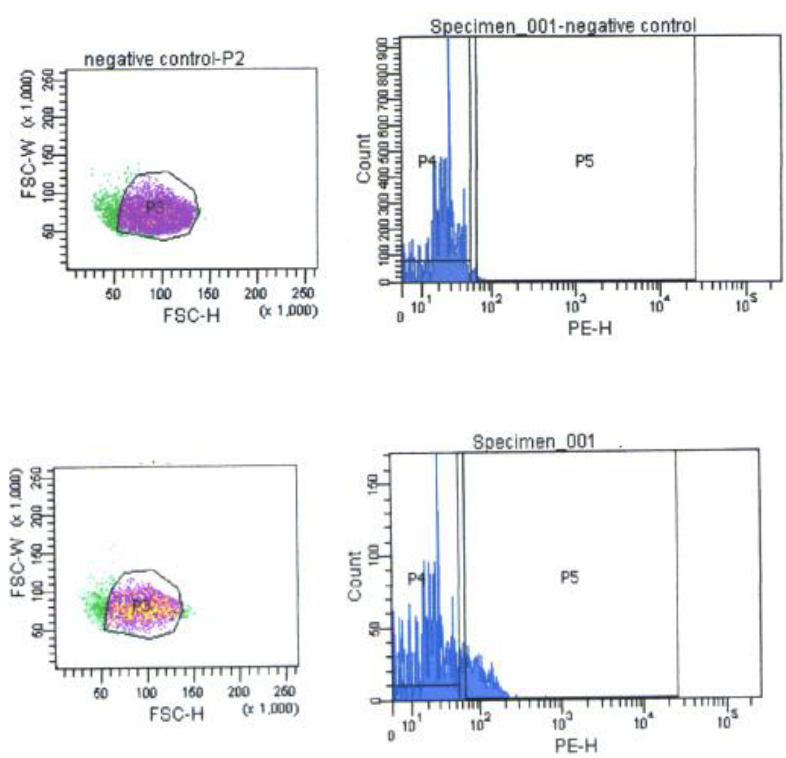

PE-H

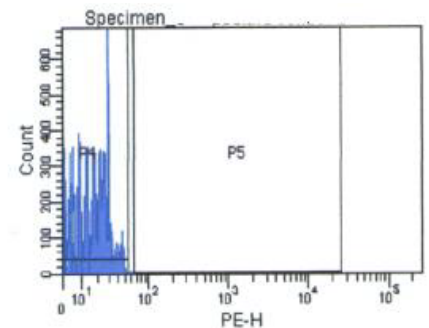

Figure 3: CD133 expression results by FACS A: Cos7 cells as negative control; B: liver tumor cells as positive control; C: CSCs derived from neuroblastoma 


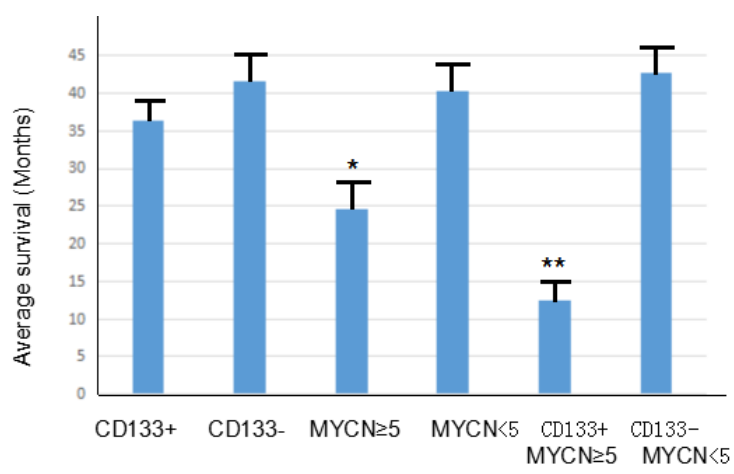

Figure 4: Correlation between $\mathrm{CD} 133$ and $\mathrm{MYCN}$ amplification with chemical therapy responses and average survival time of the NB patients. ${ }^{*} \mathrm{P}<0.05$; ${ }^{* *} \mathrm{P}<0.01$. CD133+ and/or MYCN $\geq 5$ can significantly decrease response to chemical therapy comparing with CD133- and/or $\mathrm{MYCN}<5 \quad(\mathrm{P}<0.05)$. $\mathrm{CD} 133+$ and $\mathrm{MYCN} \geq 5$ significantly reduce average survival time comparing with other options $(P<0.01)$.

is not rare to find some NB patients relapse after very good response to chemotherapy. This suggests that there is self-renewing, multi-potent cancer stem cells existing in the NB tumor tissue, and these cells induce chemo-resistance. In this study, we demonstrated that there are CSCs existing in the NB tissue, and these CSCs are CD133 positive and can differentiate into neuron like cells. The ratio of CD133 positive cells are around $0.1 \%$. There are some NB patients are CD133 negative but have shorter average survival time, indicating that the CD133 antibody epitope affinity and neuropheres culture conditions might reduce the selection efficiency. Better culture condition and stable cell separation skills are required in the further studies.

MYCN amplification level has been recognized as a predictor for disease progression. In this study, we demonstrated that CD133 can be used as a response indicator for chemotherapy. The CD133 positive NB patients have significantly worse response comparing with the CD133 negative NB patients. MYCN and CD133 together can be used as indicators for the average survival time of the NB patients. We only recruited 50 patients into this study, bigger study groups are needed in the further studies.

It has been demonstrated that Valproic Acid (VPA), as HDAC inhibitor can increase CD133+ cells and show low sensitivity to cytostatics in NB [22]. The epigenetic effect of the HDAC inhibitor suggests that the viability of the $\mathrm{CD} 133$ protein expression is related to the acetylation of histones and methylation status of the CD133 promoter. This means that the CD133 gene promoter might be considered as a target for drug exploration.

In this study, we excluded the NB patients who receive autologous peripheral blood stem cell transplantation (APBSCT) and/or immunotherapy due to uncertainty of these treatments. In our future study, we shall closely observe the clinical effects of these two methods and recruit these patients into our study.

Overall, we demonstrate that CD133+ cells exist in the NB tissue, and these cells are self-renewing and multi-potent stem cells. CD133+ CSCs produce chemo-resistance. CD133 and MYCN amplification can be used together as a prognostic value for predicting disease outcome.

\section{Ethics Approval and Consent to Participate}

This study was reviewed and approved by The Second hospital of Hebei Medical University Ethics Committee before the study began. Written informed consent was provided to participate recruited into this study.

\section{Funding}

This study is funded by the Hebei Province Health Department Fund for Excellence Clinical Doctor.

\section{Author Contribution}

Dr. Zhi-Yong Zhong organize this study and wrote the manuscript. Dr. Bao-Jun Shi and Dr. Hui Zhou collect samples and some of lab works. Dr. Wen-Bo Wang analyze the data.

\section{References}

1. Neuroblastoma treatment (2002-2016) PDQ Pediatric Treatment Editorial Board. PDQ Cancer Information Summaries. Bethesda (MD):National Cancer Institute, US.

2. World cancer report (2014) World Health Organization.

3. Maris JM, Hogarty MD, Bagatell R, Cohn SL (2007) Neuroblastoma. Lancet 369: 2106-2020. [PubMed]

4. Brodeur GM (2003) Neuroblastoma: biological insights into a clinical enigma. Nat Rev Cancer 3: 203-216. [PubMed]

5. Newman EA, Nuchtern JG (2016) Recent biologic and genetic advances in neuroblastoma: Implications for diagnostic, risk stratification, and treatment strategies. Semin Pediatr Surg 25: 257-264.

6. Davidoff AM, Fernandez-Pineda I (2016) Complications in the surgical management of children with malignant solid tumors. Semin Pediatr Surg 25 395-403. [PubMed]

7. Ward E, DeSantis C, Robbins A, Kohler B, Jemal A (2014) Childhood and adolescent cancer statistics, 2014. CA Cancer J Clin 64: 83-103. [PubMed]

8. London WB, Castleberry RP, Matthay KK, Look AT, Seeger RC, et al. (2005) Evidence for an age cutoff greater than 365 days for neuroblastoma risk group stratification in the Children's Oncology Group. J Clin Oncol 23: 6459-6465. [PubMed]

9. Citak C, Karadeniz C, Dalgic B, Oguz A, Poyraz A, et al. (2006) Intestinal lymphangiectasia as a first manifestation of neuroblastoma. Pediatr Blood Cancer 46: 105-107. [PubMed]

10. Bourdeaut F, de Carli E, Timsit S, Coze C, Chastagner P, et al. (2009) VIP hypersecretion as primary or secondary syndrome in neuroblastoma: $A$ retrospective study by the Société Française des Cancers de l'Enfant (SFCE). Pediatr Blood Cancer 52: 585-590. [PubMed]

11. Smith MA, Altekruse SF, Adamson PC, Reaman GH, Seibel NL (2014) Declining childhood and adolescent cancer mortality. Cancer 120: 2497-2506. [PubMed]

12. Reya T, Morrison SJ, Clarke MF, Weissman IL (2001) Stem cells, cancer, and cancer stem cells. Nature 414: 105-111. [PubMed]

13. Dick JE (2008) Stem cell concepts renew cancer research. Blood 112: 4793807. [PubMed]

14. Visvader JE, Lindeman GJ (2008) Cancer stem cells in solid tumours: accumulating evidence and unresolved questions. Nat Rev Cancer 8: 755-768. [PubMed]

15. Clarke MF, Dick JE, Dirks PB, Eaves CJ, Jamieson CH, et al. (2006) Cancer stem cells-perspectives on current status and future directions: AACR Workshop on cancer stem cells. Cancer Res 66: 9339-9344. [PubMed]

16. Walton JD, Kattan DR, Tomas SK, Spengler BA, Guo HF, et al. (2004) Characteristics of stem cells from human neuroblastoma cell lines and in tumors. Neoplasia 6: 838-845. [PubMed]

17. Ross RA, Spengler BA, Domènech C, Porubcin M, Rettig WJ, et al. (1995) Human neuroblastoma I-type cells are malignant neural crest stem cells. Cell Growth Differ 6: 449-456. [PubMed]

18. Hansford LM, McKee AE, Zhang L, George RE, Gerstle JT, et al. (2007) Neuroblastoma cells isolated from bone marrow metastases contain a naturally enriched tumor-initiating cell. Cancer Res 67: 11234-11243. [PubMed] 
Citation: Zhong ZY, Shi BJ, Zhou H, Wang WB (2017) CD133 and MYCN Amplification Induce Chemo-Resistance and Reduce Average Survival Time in Pediatric Neuroblastoma. J Stem Cell Res Ther 7: 394. doi: 10.4172/2157-7633.1000394

Page 7 of 7

19. Corbeil D, Fargeas CA, Huttner WB (2001) Rat prominin, like its mouse and human orthologues, is a pentaspan membrane glycoprotein. Biochem Biophys Res Commun 285: 939-944. [PubMed]

20. Zacchigna S, Oh H, Wilsch-Bräuninger M, Missol-Kolka E, Jászai J, et al. (2009) Loss of the cholesterolbinding protein prominin-1/CD133 causes disk dysmorphogenesis and photoreceptor degeneration. J Neurosci 29: $2297-$ 2308. [PubMed]

21. Khalil MA, Hraběta J, Groh T, Procházka P, Doktorová H, et al. (2016) Valproic Acid increases CD133 positive cells that show low sensitivity to cytostatics in neuroblastoma. PLoS One 11: e0162916. [PubMed]

22. Ambros PF, Ambros IM, Brodeur GM, Haber M, Khan J, et al. (2009) International consensus for neuroblastoma molecular diagnostics: report from the International Neuroblastoma Risk Group (INRG) Biology Committee. Br J Cancer 100: 1471-1482. [PubMed]

23. Kreissman SG, Seeger RC, Matthay KK, London WB, Sposto R, et al. (2013) Purged versus non-purged peripheral blood stem-cell transplantation for high- risk neuroblastoma (COG A3973): a randomised phase 3 trial. Lancet Oncol 14 (10): 999-1008. [PubMed]

24. Defferrari R, Mazzocco K, Ambros IM, Ambros PF, Bedwell C, et al. (2015) Influence of segmental chromosome abnormalities on survival in children over the age of 12 months with unresectable localised peripheral neuroblastic tumours without MYCN amplification. Br J Cancer 112: 290-295. [PubMed]

25. Bagatell $R$, Beck-Popovic $M$, London WB, Zhang $Y$, Pearson $A D$, et al. (2009) Significance of MYCN amplification in international neuroblastoma staging system stage 1 and 2 neuroblastoma: a report from the International Neuroblastoma Risk Group database. J Clin Oncol 27: 365-370. [PubMed]

26. Brodeur GM, Pritchard J, Berthold F, Carlsen NL, Castel V, et al. (1993) Revisions of the international criteria for neuroblastoma diagnosis, staging, and response to treatment. J Clin Oncol 11: 1466-1477. [PubMed]

27. Cohn SL, London WB, Monclair T, Matthay KK, Ambros PF, et al. (2007) Update on the development of the international neuroblastoma risk group (INRG) classification schema. JCO 25: 9503. 